\title{
Insect Olfactory Neurons in vitro: Morphological and Physiological Characterization of Cells from the Developing Antennal Lobes of Manduca sexta
}

\author{
Jon H. Hayashi and John G. Hildebrand \\ Arizona Research Laboratories, Division of Neurobiology, University of Arizona, Tucson, Arizona 85721
}

To facilitate studies of the development and membrane biophysics of cells in the central olfactory pathway of the moth Manduca sexta, we have dissociated neurons and glial cells from the antennal lobes (ALs) and cultivated them in the controlled environment of tissue culture. Cultures produced from cells of the lateral group of AL neurons alone are enriched in local interneurons (LNs), while cultures made from cells of the median and anterior groups of AL neurons contain projection neurons (PNs) but lack LNs. Cultures containing only PNs, but not cultures with both PNs and LNs, require a conditioning factor derived from a conspecific cell line in order to ensure survival. Under these conditions, we identify 5 types of cells in the "PN-only" cultures that are consistently observed and distinguishable on the basis of their morphology and characteristic whole-cell current profiles. In cultures that contain both PNs and LNs, we find 3 additional types of cells with neuronlike appearance. Whereas the PNs have whole-cell currents that suggest a neuronal phenotype, we have not yet observed similar currents in the 3 other types of cells. We tentatively identify the latter 3 cell types as LNs whose development has been arrested. The conditioning factor also has a trophic effect on phase-dark, multipolar cells that are observed in freshly dispersed cultures. Their morphology and whole-cell currents lead us to suggest that they are glial cells.

The antennal lobe (AL), the first central olfactory processing station in insects, has been studied extensively in the sphinx moth Manduca sexta. The neurons of the AL, both amacrine local interneurons (LNs) and projection neurons (PNs), have

\footnotetext{
Received July 6, 1989; revised Sept. 7, 1989; accepted Sept. 14, 1989.

We are indebted to Drs. Steven G. Matsumoto, Karen A. Gregerson, and Sue $C$. Kinnamon for invaluable advice on tissue culture and patch-clamp techniques. Drs. Lynne A. Oland, Leslic P. Tolbert, and Richard B. Levinc provided helpful comments and criticism in the course of this research and on the manuscript. We thank Anastasia L. Peterson, and Galya Orr for technical assistance, Deborah Sakiestewa and Peggy Randolph for assistance with insect rearing, and Charles Hedgcock for photographic assistance. Drs. James Buckner and James Svoboda of the USDA generously supplied $M$. sexta eggs, and Dr. Dwight E. Lynn (USDA) kindly gave us the $M$. sexta cell line, as well as information about maintaining it. This research was supported by a grant from Monsanto Company and by NIH Grant AI-23253, as well as by NRSA postdoctoral research fellowship NS-08010 to JHH.

We dedicate this paper to the memories of our friends and colleagues Laura $M$. Griffin and Stephen M. Schuetze, both of whom gave us valuable help in the course of this research.

Correspondence should be addressed to Dr. Jon H. Hayashi, ARL Division of Neurobiology, 611 Gould-Simpson Building, University of Arizona, Tucson, AZ 85721 .

Copyright (C) 1990 Society for Neuroscience $0270-6474 / 90 / 030848-12 \$ 02.00 / 0$
}

their somata in 3 distinct and separate groups lying in characteristic locations in the lateral, medial, and anteroventral $\mathrm{AL}$ (Christensen and Hildebrand, 1987; Homberg et al., 1988, 1989) (Fig. 1). The medial group (ca. 200 somata) and the anteroventral group (ca. 16 somata) apparently contain only PNs, while the large lateral group (ca. 1,000 somata) comprises a mixed population of LNs and PNs (Homberg et al., 1989).

A substantial body of information exists about the electrophysiological responses of these neurons to primary-afferent input (Matsumoto and Hildebrand, 1981; Christensen and Hildebrand, 1987, 1988; Waldrop et al., 1987; Kanzaki et al., 1989; Waldrop and Hildebrand, 1989), their neuroanatomy (Tolbert and Hildebrand, 1981; Hoskins et al., 1986; Homberg et al., 1989), their neurochemistry (Prescott et al., 1977; Sanes et al., 1977; Kingan and Hildebrand, 1985; Hoskins et al., 1986; Kent et al., 1987), and their morphological and electrophysiological maturation during postembryonic, metamorphic adult development (Schneiderman et al., 1982; Tolbert et al., 1983; Hildebrand, 1985). Numerous specific questions remain, however, about the membrane currents that underlie the observed physiological responses. Information about the membrane physiology of AL cells during postembryonic, metamorphic adult development will help us understand better how these cells mature as well as how the AL integrates and processes sensory information. Progress in this area has been limited by the difficulty of voltage-clamping the AL neurons in situ, because their arborizations are prohibitively extensive and their synaptic interactions, complex. To facilitate developmental and biophysical studies, we have developed a primary culture system in which dispersed cells can be continually observed and are accessible to patch-clamp techniques.

The culture system presented here supports the development and long-term maintenance of AL neurons and glial cells in vitro and has permitted the first whole-cell patch-clamp recordings from these CNS cells. We describe 5 morphological types of AL PNs, each of which expresses a characteristic complement of voltage-gated currents typical of neurons, and 3 morphological cell types that are unique to cultures enriched in LNs and appear to be physiologically immature. Glial cells, which in our cultures thrive only in the presence of medium ("embo-CM") conditioned by an embryonic $M$. sexta cell line, exhibit outward currents that activate slowly.

Preliminary accounts of some of this work have appeared elsewhere (Hayashi and Hildebrand, 1988, 1989). Together with companion studies of primary olfactory receptor cells in vitro (Stengl and Hildebrand, 1988, 1990; Stengl et al., 1989), this work opens the way to future studies of mechanisms that control 
the development of neurons and synapses in the insect olfactory system.

\section{Materials and Methods}

\section{Animals}

Manduca sexta (Lepidoptera:Sphingidae) were reared from eggs on artificial diet (modified from Bell and Joachim, 1976) on a long-day photoperiod regimen ( $17 \mathrm{hr}$ light $/ 7 \mathrm{hr}$ dark) at $26^{\circ} \mathrm{C}$ and $50-60 \%$ relative humidity. Metamorphic adult development begins soon after the molt of the larva to the pupa and proceeds through 18 stages. Pupae were staged as previously described (Sanes and Hildebrand, 1976; Tolbert et al., 1983).

\section{Dissection and dissociation of cells}

Brains were isolated by dissection with aseptic technique from coldanesthetized pupae and transferred to sterile culture saline (see below) in a $35-\mathrm{mm}$ sterile plastic dish. The ALs are distinct at every stage and are the most anterior structures in the brain (Fig. 1). Using the meshwork of tracheae that forms a line of demarcation between the AL and adjacent brain tissue as a landmark, we dissected the $\Lambda$ Ls from the brain. The perineurium was gently peeled away to expose the underlying groups of neuronal somata and to minimize the number of perineurial cells in the cultures.

Because the lateral group of AL neurons comprises both LNs and PNs, whereas the medial and anteroventral groups apparently are composed exclusively of PNs, PN-only cultures could be produced by dissociation of ALs after the lateral group had been excised and discarded. Alternatively', dissociation and culturing of cells from entire ALs or from the isolated lateral group generated cultures that contained both LNs and PNs. Before stage 4, however, we could not confidently dissect away the lateral cell group because the 3 cell groups have not yet become clearly demarcated.

We produced cell cultures from ALs of developing adults at stages 4-18, i.e., from cells that had developed for different amounts of time in vivo. While neurons dissociated from later stages appeared to be as robust as cells from earlier stages, we routinely used animals at stages 4 and 5 because neurons cultured from ALs at these stages had lie highest rate of survival (ca. $40 \%$ ).

The tissue to be dissociated was incubated for $5 \mathrm{~min}$ at $37^{\circ} \mathrm{C}$ in $2 \mathrm{ml}$ of Hanks' $\mathrm{Ca}^{2+}$ - and $\mathrm{Mg}^{2+}$-free balanced salt solution (GIBCO) containing $0.5 \mathrm{mg} / \mathrm{ml}$ collagenase (Cooper Biomedical, type I, CLS 4196) and $2 \mathrm{mg} / \mathrm{ml}$ Dispase (Boehringer Mannheim, grade II, protease neutral, 165859 ). The tissue was then dispersed by trituration with a fire-polished Pasteur pipette. The action of the enzymes was terminated by centrifugation of the cells first through $6 \mathrm{ml}$ of culture saline (see below) and then through $6 \mathrm{ml}$ of I-L 5 culture medium (see below). The pellet was resuspended in sufficient I-L15 medium or conditioned medium ("embo-CM," see below) to plate cells from one pair of ALs in a culture well with a diameter of $8 \mathrm{~mm}$. The cells settled and adhered to the coated surface (see below) of the well in $1.5 \mathrm{hr}$, after which the dish was flooded with an additional $2 \mathrm{ml}$ of medium. These cultures were maintained at $26^{\circ} \mathrm{C}$ in a humidified incubator with normal air.

\section{Media}

Culture saline. Saline solution used in the dissociation of cells consisted of $149.9 \mathrm{mM} \mathrm{NaCl}, 3 \mathrm{mM} \mathrm{KCl}, 3 \mathrm{mM} \mathrm{CaCl}, 0.5 \mathrm{mM} \mathrm{MgCl}_{2}, 10 \mathrm{~mm}$ $\mathrm{N}$-tris-(hydroxymethyl)-methyl-2-aminoethane sulfonic acid (TES, Research Organics), $11 \mathrm{~mm}$ D-glucose, $5 \mathrm{~g} /$ liter lactalbumin hydrolysate (GIBCO), $5 \mathrm{~g} /$ liter TC Yeastolate (Difco), 10\% fetal bovine serum (FBS, Hyclone), 100 units/ml penicillin, $100 \mu \mathrm{g} / \mathrm{ml}$ streptomycin, $\mathrm{pH} \mathrm{7,360}$ mOsm. This formulation is a modification of the insect tissue culture medium described by Mitsuhashi and Maramorosch (1964).

Culture medium. I-L1 5 (our supplemented version of Leibovitz's L15 medium) consisted of $500 \mathrm{ml}$ of L15 to which had been added $10 \%$ FBS, $185 \mathrm{mg} \alpha$-ketoglutaric acid, $200 \mathrm{mg} \mathrm{D}-(-)$-fructose, $350 \mathrm{mg}$ D-glucose, $335 \mathrm{mg}$ D-L-malic acid, $30 \mathrm{mg}$ succinic acid, $1.4 \mathrm{gm}$ TC Yeastolate, $1.4 \mathrm{gm}$ lactalbumin hydrolysate, $0.01 \mathrm{mg}$ niacin, $30 \mathrm{mg}$ imidazole, 500 $\mu \mathrm{g} 20$-hydroxyecdysone (20-HE, Sigma E-2003), $100 \mathrm{units} / \mathrm{ml}$ penicillin, $100 \mu \mathrm{g} / \mathrm{ml}$ streptomycin, and $2.5 \mathrm{ml}$ stable vitamin mix. A $5 \mathrm{ml}$ stock solution of stable vitamin mix (Mains and Patterson, 1973) consisted of $15 \mathrm{mg}$ aspartic acid, $15 \mathrm{mg}$ cystine, $5 \mathrm{mg} \beta$-alanine, $0.02 \mathrm{mg}$ biotin, $2 \mathrm{mg}$ vitamin $\mathrm{B}_{12}, 10 \mathrm{mg}$ inositol, $10 \mathrm{mg}$ choline chloride, 0.5 $\mathrm{mg}$ lipoic acid, $5 \mathrm{mg} p$-aminobenzoic acid, $25 \mathrm{mg}$ fumaric acid, $0.4 \mathrm{mg}$

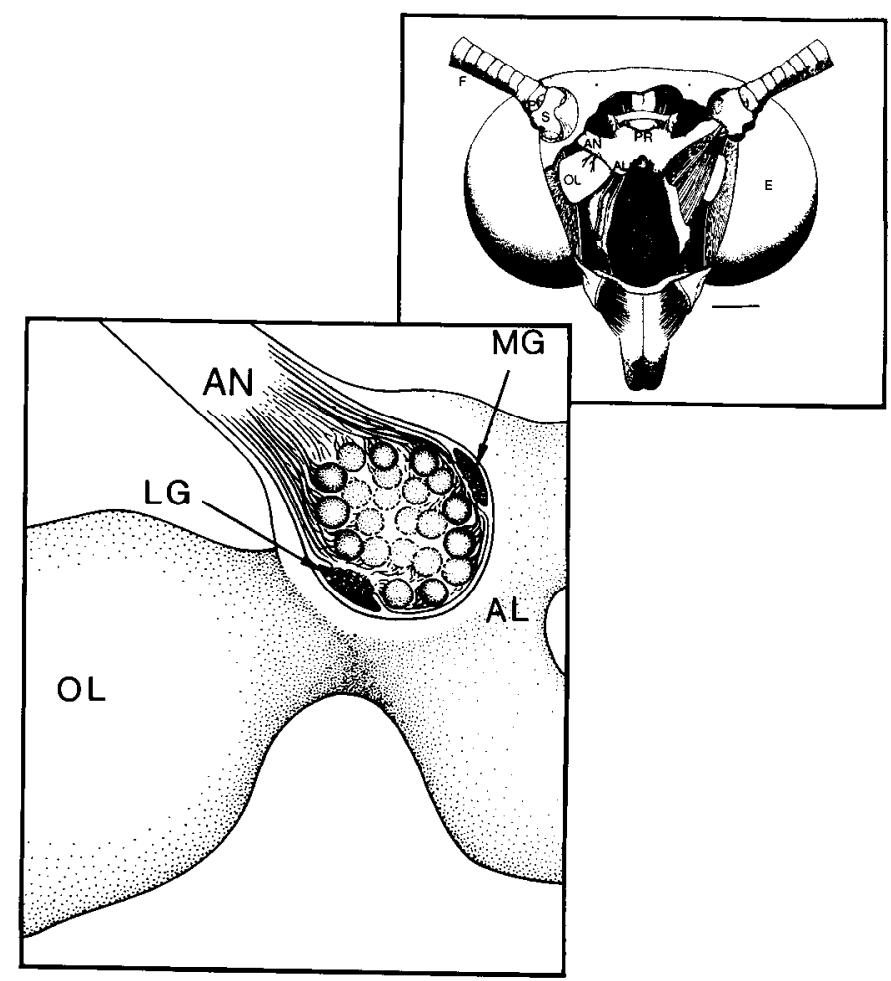

Figure 1. Upper right, Cutaway view exposing the brain of Manduca sexta (dorsal aspect). $F$, antennal flagellum; $P$, pedicel; $S$, scape; $A N$, antennal nerve; $A L$, antennal lobe; $P R$, protocerebrum; $E$, compound eye; $O L$, optic lobe. Scale bar, $1 \mathrm{~mm}$. Lower left, Frontal cutaway vicw of the antennal lobe illustrating two of the three groups of neuronal somata that border the glomerular neuropil of the $\mathrm{A} L: L G$, lateral cell group; $M G$, medial cell group. The anteroventral group of about 13 cell bodies is not visible in this view.

coenzyme A (P-L Biochemicals), $15 \mathrm{mg}$ glutamic acid, and $0.5 \mathrm{mg}$ phenol red. The pH was adjusted to 7.0 , and the osmolarity, to 350 mOsm with mannitol. All media were sterilized by filtration through a $0.22 \mu \mathrm{m}$ filter (Falcon 7107) and stored at $5^{\circ} \mathrm{C}$. Thus, our supplementation of L15 medium involves the addition of FBS, stable vitamin mix, components (except for inorganic salts) that are present in Grace's insect medium (Grace, 1962) but not in L-15, lactalbumin hydrolysate and Yeastolate [which are components of the medium of Mitsuhashi and Maramorosch (1964)], and $1 \mu \mathrm{g} / \mathrm{ml}$ of 20-HE. This level of $20-\mathrm{HE}$ was based upon the finding that, during metamorphic adult development, the concentration of $20-\mathrm{HE}$ in hemolymph climbs from undetectable to roughly $3.5 \mu \mathrm{g} / \mathrm{ml}$ (Warren and Gilbert, 1986). 20-HE enhanced neuronal survival and resulted in the growth of fuller arborizations in our cultures. The appropriate osmolarity is $360 \mathrm{mOsm}$ (L. Tolbert, personal communication), but I-L15 was adjusted (with mannitol) to 10 mOsm below this value to compensate for the very low ambient humidity in Arizona.

We did not find the addition of whole chicken-egg ultrafiltrate (Yunker et al., 1967) or bovine albumin fraction V (Sigma A2153) to be beneficial. Also without benefit was the addition of $M$. sexta hemolymph (up to $40 \mu \mathrm{l}$ in $2 \mathrm{ml}$ ) taken from stage-5 pupae.

$M$. sexta AL neurons have growth requirements that differ from those reported for other insect neurons. For example, " $5+4$ medium" used for cockroach (Chen and Levi-Montalcini, 1969) and locust (Giles and Usherwood, 1985) cells did not produce satisfactory results with $M$. sexta neuronal cultures. Modified Schneider's medium (Seecof and Donady, 1972; Dewhurst and Beadle, 1985), which has been used successfully for cultures of cells from Drosophila melanogaster, also proved unsatisfactory for our cultures.

Medium for patch-clamp experiments. Patch-clamp experiments required the development of a medium that would support neuronal viability for a few hours but consist only of inorganic salts, because serum prevented the formation of very high resistance seals between the patch-clamp electrode and the cell membrane. We used an artificial 

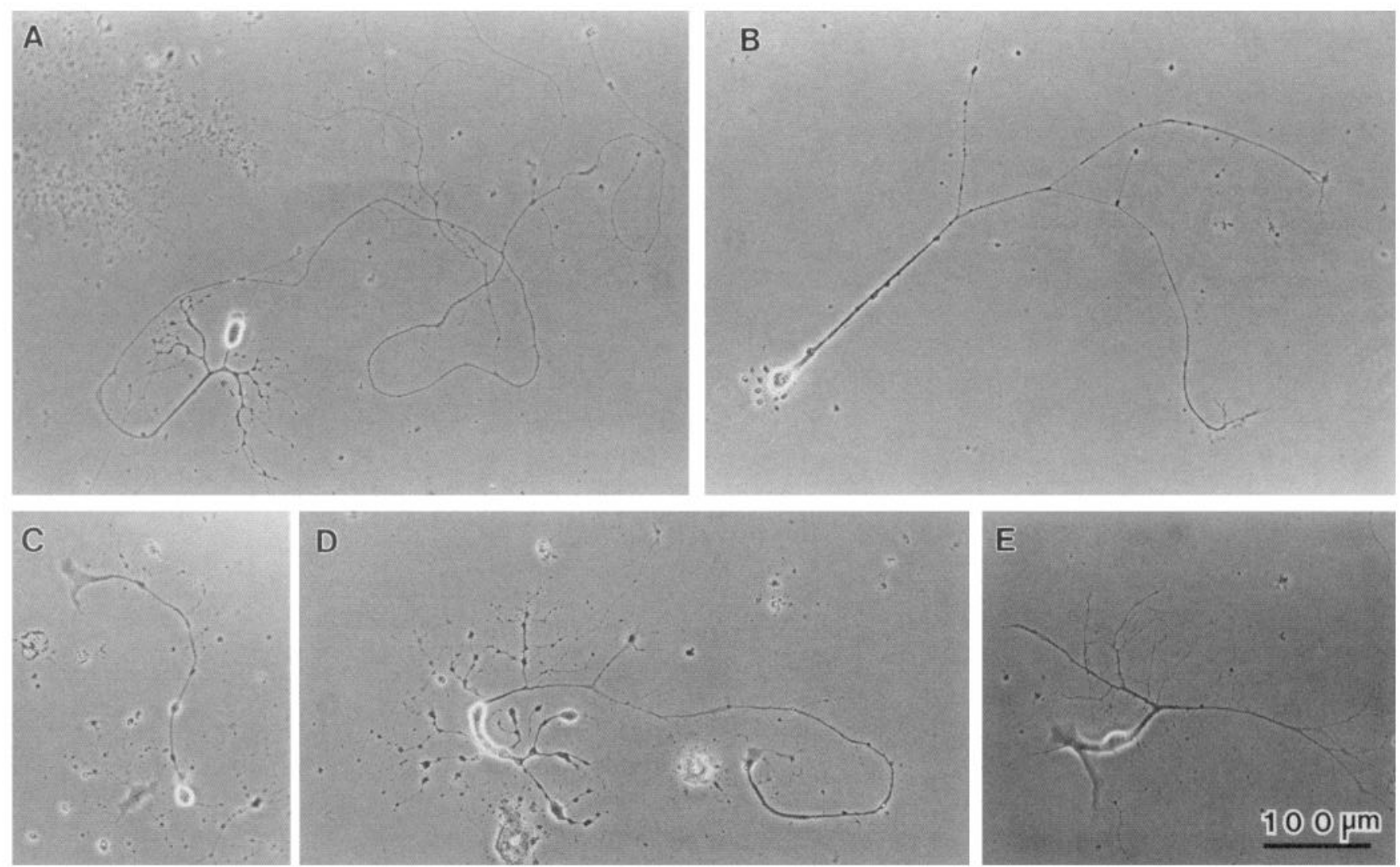

Figure 2. Morphology of PNs after $10 \mathrm{~d}$ in culture. A, Proximally branching neuron exhibits a bushy arborization that is adjacent to the soma, as well as slender and infrequently branching processes that extend across the dish for hundreds of microns. $B$, Tracery neuron is another kind of PN that has fine processes tipped with compact growth cones bearing filopodia. $C, C l u b$ neuron is a monopolar neuron that is characterized by a thick projection with a flattened growth cone. $D$, Radial neuron is characterized by an elongate soma that extends multiple processes. One of these processes continues to extend and is tipped with a structure resembling a growth cone. E, Bifurcating neuron has neurites that branch sharply and extend processes in both directions. This classification is based upon observations of cultures derived from 23 different dissociation experiments.

insect saline (AIS) that had the same $\mathrm{NaCl}$ concentration as the saline used for in situ electrophysiological experiments in our laboratory (Narahashi, 1963; Pichon et al., 1972; Waldrop and Hildebrand, 1987) but was otherwise modified to have the following composition: $150 \mathrm{~mm}$ $\mathrm{NaCl}, 4 \mathrm{~mm} \mathrm{KCl}, 6 \mathrm{~mm} \mathrm{CaCl}_{2}, 10 \mathrm{~mm}$ Hepes, $5 \mathrm{~mm}$ tissue-culture grade glucose, $\mathrm{pH} 7.0$ and osmolarity adjusted to $360 \mathrm{mOsm}$ with mannitol. This AIS formulation was found empirically to give stable recording conditions. Continuous superfusion of the preparation during our biophysical experiments eliminated the desiccation problem, and osmolarity was set at $360 \mathrm{mOsm}$.

Conditioned medium. Medium conditioned by an embryonic $M$. sexta cell line (MRRL-CH1, Eide et al., 1975) enhanced the robustness of our cultures. The cell line (generously provided by Dr. Dwight Lynn, Insect Pathology Laboratory, U.S. Department of Agriculture) was grown in modified TNM-FH medium (D. Lynn, personal communication, hereafter referred to simply as TNM-FH medium) consisting of $500 \mathrm{ml}$ Grace's insect saline (GIBCO), $1.5 \mathrm{gm}$ T.C. Yeastolate (Difco), $1.5 \mathrm{gm}$ lactalbumin hydrolysate (GIBCO), and $50 \mathrm{ml}$ fetal bovine serum (Hyclone), in $50 \mathrm{ml}$ tissue culture flasks (Falcon 3013). These cells were grown at $26^{\circ} \mathrm{C}$ and reached confluence in 3-4 weeks, after which conditioned TNM-FH medium was drawn off with a sterile pipette and centrifuged for $10 \mathrm{~min}$ at $4000 \mathrm{rpm}$ in $25 \mathrm{ml}$ Corex tubes in an SS-34 rotor of a Sorvall $\mathrm{RC}-5 \mathrm{~B}$ high-speed centrifuge running at $5^{\circ} \mathrm{C}$. The supernatant solution was then sterilized by filtration through a $0.22 \mu \mathrm{m}$ filter (Falcon 7107) and stored at $5^{\circ} \mathrm{C}$. The "embo-CM" in which our cells were cultured consisted of $20 \%$ conditioned TNM-FH medium and $80 \%$ I-L 15 . This medium promoted the survival and shape change of glial cells and enhanced neuronal survival.

\section{Culture substrate}

Cells were grown in miniwells made by sealing a glass coverslip with Sylgard (Dow 184 silicone elastomer) to the bottom of an 8-mm hole in the bottom of a 35-mm plastic dish (Corning 25000) (Bray, 1970; Hawrot and Patterson, 1979). The dishes were sterilized by UV irradiation, and the glass was coated by exposure to a solution of $200 \mu \mathrm{g}$ $\mathrm{ml} \mathrm{Concanavalin} \mathrm{A} \mathrm{(Con} \mathrm{A,} \mathrm{Sigma} \mathrm{C-2010)} \mathrm{and} 2 \mu \mathrm{g} / \mathrm{ml}$ laminin (Collaborative Research 40232 ) for $2 \mathrm{hr}$ at $37^{\circ} \mathrm{C}$ in a humid environment. The dishes were then rinsed with a stream of sterile water $(6 \mathrm{ml})$ and air-dried in a sterile tissue culture hood. We used this miniwell technique because glass coverslips offer optical properties that are superior to those of plastic culture dishes and permit observation of cells with Nomarski DIC optics. In addition, the glass surfaces are resistant to propylene oxide (used in fixation of tissue for electron microscopy). The plant lectin Con A (DeGeorge et al., 1985; Chiquet and Acklin, 1986; Pinnock and Sattelle, 1987; Ross et al., 1987) allows AL cells to adhere and extend processes. We did not determine whether the contribution of laminin is receptor-mediated or whether it acts to prevent Con A from washing off the surface over time. Laminin alone did not allow cells to adhere to the surface.

Experiments with tissue culture plasticware alone yielded unsatisfactory results. Adhesion of cells was tenuous at best with Linbro multiwell plates (Flow Laboratories, Inc.), Corning multiple-well plates (Corning Glass Works), GIBCOware (GIBCO), and Falcon 3001 and Falcon Primaria $35 \mathrm{~mm}$ plates (Becton Dickinson). Pressing the tissue onto plastic or uncoated glass surfaces (Chen and Levi-Montalcini, 1969) with sterile polycarbonate filter membranes (Nuclepore) also proved futile. The 
charged coating substances poly-D-lysine hydrobromide (high molecular weight, Collaborative Research) or poly-ornithine (Sigma) also did not promote sufficient adhesion of AL cells to the surface. Cells did adhere to surfaces coated with marine-mussel adhesive protein (Cell-Tak, Biopolymers Inc.), but adhesivity declined over the course of days. Cells did not adhere to freshly extracted rat-tail collagen (modified method of Bornstein, 1958; Furshpan et al., 1986).

\section{Whole-cell patch-clamping}

Of the variety of experimental techniques that are possible, the most appropriate one for the present study was the whole-cell patch-clamp (Hamill et al., 1981; Fenwick et al., 1982) because it permits control of intracellular ionic concentrations. This gives one the ability to separate membrane currents by internal ion substitution. Patch-clamp electrodes were made fiom $1.6 \mathrm{~mm}$ (o.d.) borosilicate glass microhematocrit capillaries (Baxter Scientific Products, B4416-10) with a Narishige PP-83 puller. The patch electrode was filled with a low- $\mathrm{Ca}^{2+}$ solution (composed of $150 \mathrm{~mm} \mathrm{KAsp}$ or $\mathrm{CsCl}, 2 \mathrm{~mm} \mathrm{MgCl}_{2}, 1 \mathrm{~mm} \mathrm{CaCl}, 11 \mathrm{~mm}$ EGTA, 2 mм ATP, 5 mм Hepes, pH 7.0, and mannitol to adjust osmolarity to $330 \mathrm{mOsm}$ ). Internal patch-pipette solutions for wholecell recording required an osmolarity roughly 30 mOsm lower than that of the external saline to prevent osmotic imbalances. We assumed that internal fixed charges made this apparent inequality necessary. These pipettes had resistances of 3-5 M 2 . Just prior to the experiment, the cells were transferred to AIS (see above) in order to facilitate the formation of gigaohm seals. The headstage of an Axon Instruments Axopatch IB amplifier was held by a Leitz manipulator. The cells were visualized at $400 \times$ with an Olympus IMT-2 inverted microscope equipped with Hoffman modulation contrast optics to aid electrode placement on the cell membrane.

Generation of experimental protocols and acquisition and analysis of data were aided by pCLAMP software (Axon Instruments) running on a Compaq 386 computer. The records were low-pass filtered (4-pole Bessel) at $10 \mathrm{kHz}$. Linear leakage and capacity currents were subtracted, and series resistance compensation was used routinely.

\section{Results}

We characterized LNs, PNs, and glial cells on the basis of their morphological and biophysical properties.

\section{$P N$-only cultures}

To ascertain the morphological characteristics of PNs in vitro, we took advantage of the fact that LNs could be eliminated by removal of the lateral group of neurons prior to dissociation of the AL tissue. At the time of dispersal, stage 5, the AL is morphologically and physiologically immature. The AL neuropil has just begun to develop its adult glomerular pattern, and synapses are beginning to form but are not yet structurally or physiologically mature (Tolbert et al., 1983). Dissociated cells settle and adhere to the culture substrate as solitary somata that occasionally have short processes. These cells grow processes in vitro, and over the course of $1-2$ weeks, 5 major morphologically distinct types of cells are consistently observed (Fig. 2). These cell types are (1) proximally branching neurons, which grow a bushy arborization adjacent to the soma and then extend processes that course about the dish for hundreds of microns (Fig. $2 A)$; (2) tracery neurons, which exhibit finely branching processes with punctate growth cones tipped with filopodia (Fig. $2 B$ ); (3) club neurons, which have a lamellar growth cone and a stout process that branches infrequently (Fig. 2C); (4) radial neurons, whose somata send out multiple radiating processes, one of which becomes dominant and continues to grow while the others are stationary (Fig. 2D); and (5) bifurcating neurons, which are distinguished by a branch point adjacent to their asymmetrical soriata (Fig. 2E). Radial and bifurcating neurons, although usually present, are observed less frequently than the other cell types in our cultures. All of these cell types have well-
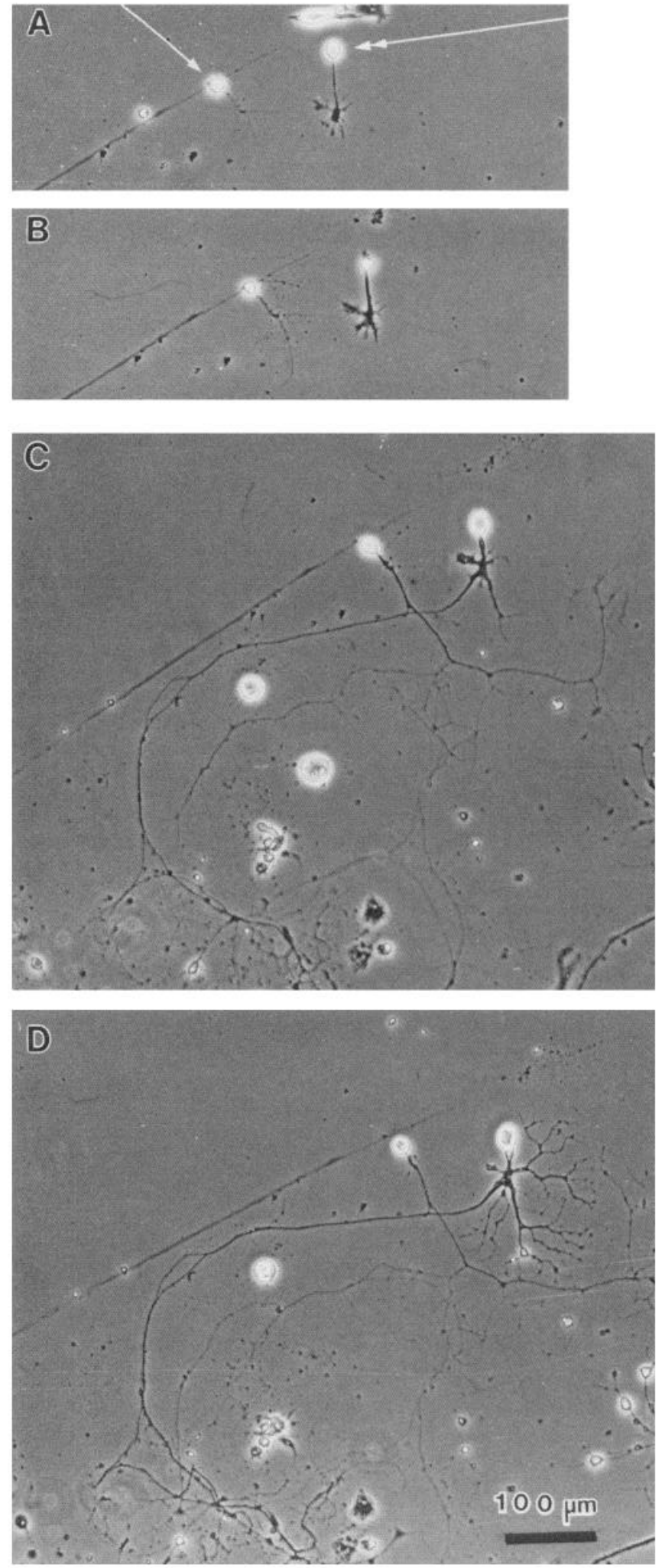

Figure 3. Time-lapse record showing the growth of a tracery neuron (arrowhead) and a proximally branching neuron (double arrowhead) along the edge of the substrate in vitro. This field was photographed on days $2(A), 7(B), 15(C)$, and $20(D)$ in culture. The processes of these cells are distinctly different even after only $2 \mathrm{~d}$ in culture. The tracery neuron elaborates thin processes, which become progressively more elaborate with time. The proximally branching neuron projects a stout process, which then sprouts a thinner branch. The arborization that arises proximal to the soma arises after day 15 in culture. 

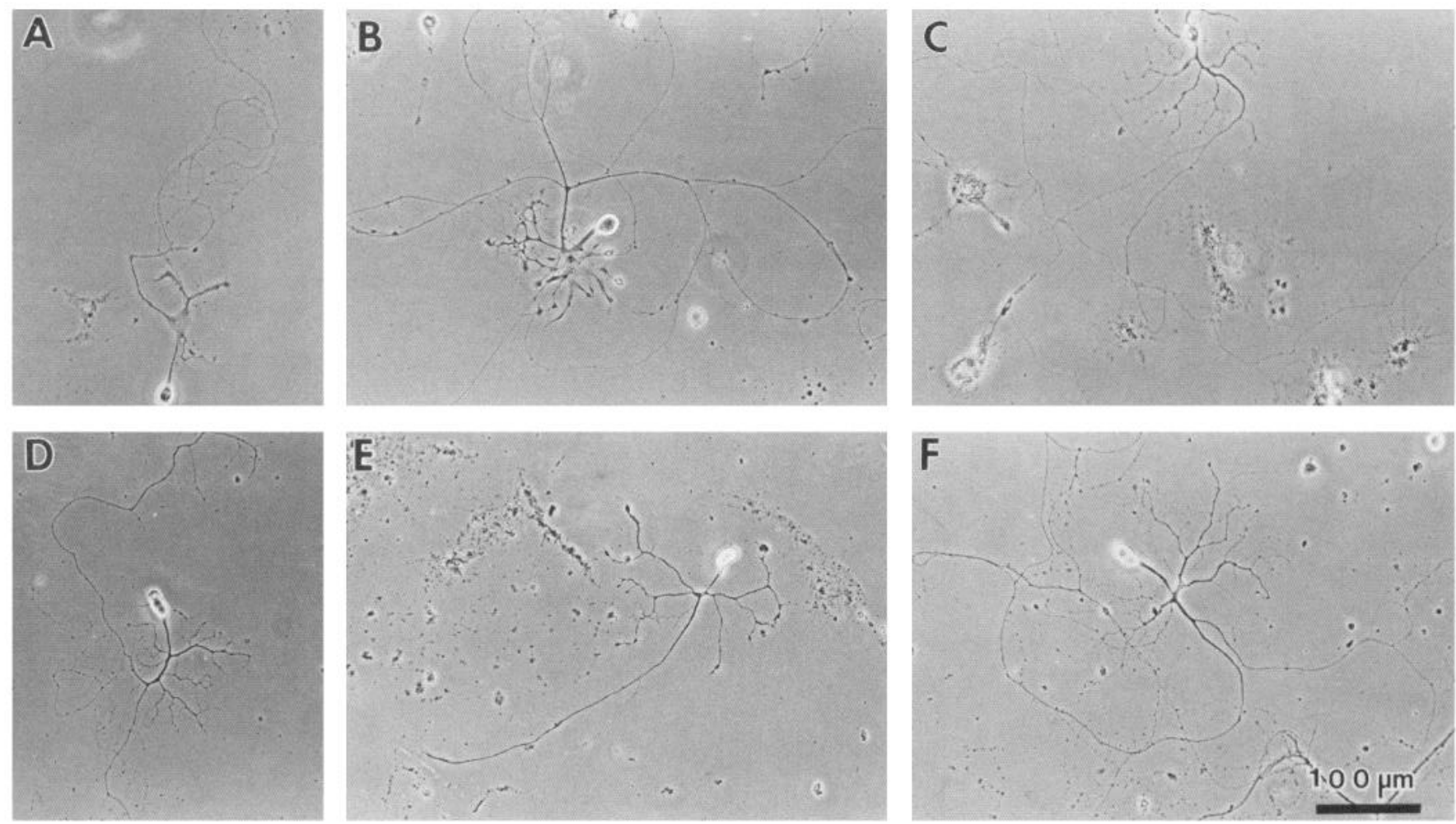

Figure 4. Six different examples of the proximally branching neuron grown in embo-CM. The time in culture for each panel was as follows: $A$, 7 $\mathrm{d} ; B$ and $C, 9 \mathrm{~d} ; D, 10 \mathrm{~d} ; E$ and $F, 27 \mathrm{~d}$.
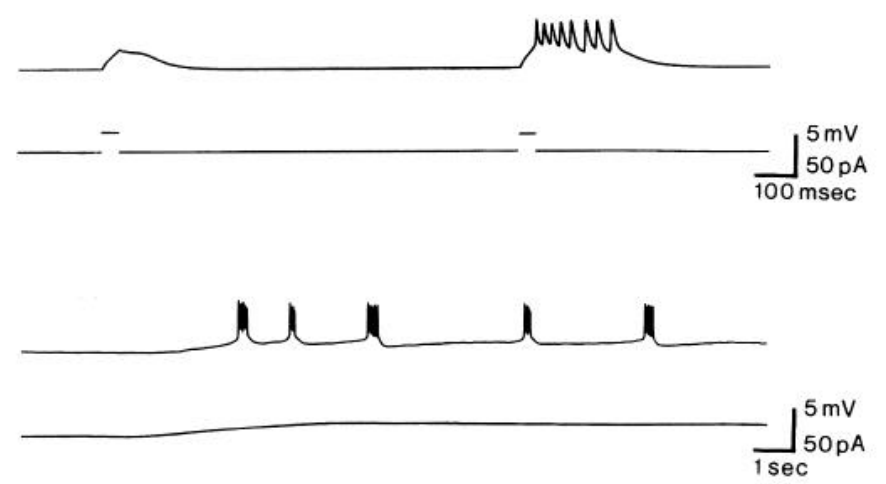

Figure 5. Whole-cell recordings made from a cultured neuron in the current-clamp mode. The upper trace in each pair of traces is the voltage record, and the lower trace is a monitor of the current passed from the electrode into the cell. $A$, When $40 \mathrm{msec}$ pulses of current were passed into the soma, the cell responded with a positive-going potential that outlasted the stimulus. When the induced depolarization exceeded a threshold, a train of action potentials was elicited. $B$, When the soma was depolarized with a continuous current, bursts of action potentials were elicited. defined, centrally placed nuclei and smooth, well-defined plasma membranes.

The morphological development of proximally branching and tracery neurons is shown in a sequence of photomicrographs made between 2 and $20 \mathrm{~d}$ in culture (Fig. 3). A proximally branching neuron, for example, can be recognized after only 2 $\mathrm{d}$ in culture by its ovoid soma and rudimentary proximal arborization with its characteristic dark and splayed-out growth cones. In culture, the morphology of a developing proximally branching neuron contrasts from day 2 onward with that of a tracery neuron with its fine processes and punctate growth cones (Fig. 3). Thus, particular morphological cell types can be distinguished after only a few days in vitro and are not merely stages in the morphological development of a single type of cell. Figure 4 shows 6 different examples of the proximally branching neuron. While there is some variability among these cells, the principal features of this cell type are exhibited in each example.

Neurons in culture can develop the ability to generate action potentials. Of particular interest is a pattern of excitability that resembles in vivo electrophysiological observations. The experimental record in Figure 5 comes from a whole-cell recording

Figure 6. Whole-cell currents characteristic of each of the 5 types of morphologically distinct PNs after $13 \mathrm{~d}$ in culture are shown on the left, and the corresponding current-voltage relations (derived from measurements made at the point of peak inward current) are shown on the right. $A$, Proximally branching neuron (typical of 11 out of 13 observations); $B$, tracery neuron (typical of 7 out of 12 observations); $C$, club neuron (typical of 13 out of 14 observations); $D$, radial neuron; $E$, bifurcating neuron (typical of 4 out of 5 observations). The $c l u b$ neuron (C) displays a slowly activating current that does not fully inactivate during the $30 \mathrm{msec}$ test pulse. The radial, tracery, and proximally branching neurons exhibit an early inward current and a late outward current like those one might expect to underlie an action potential. In $E$, squares give the peak inward 

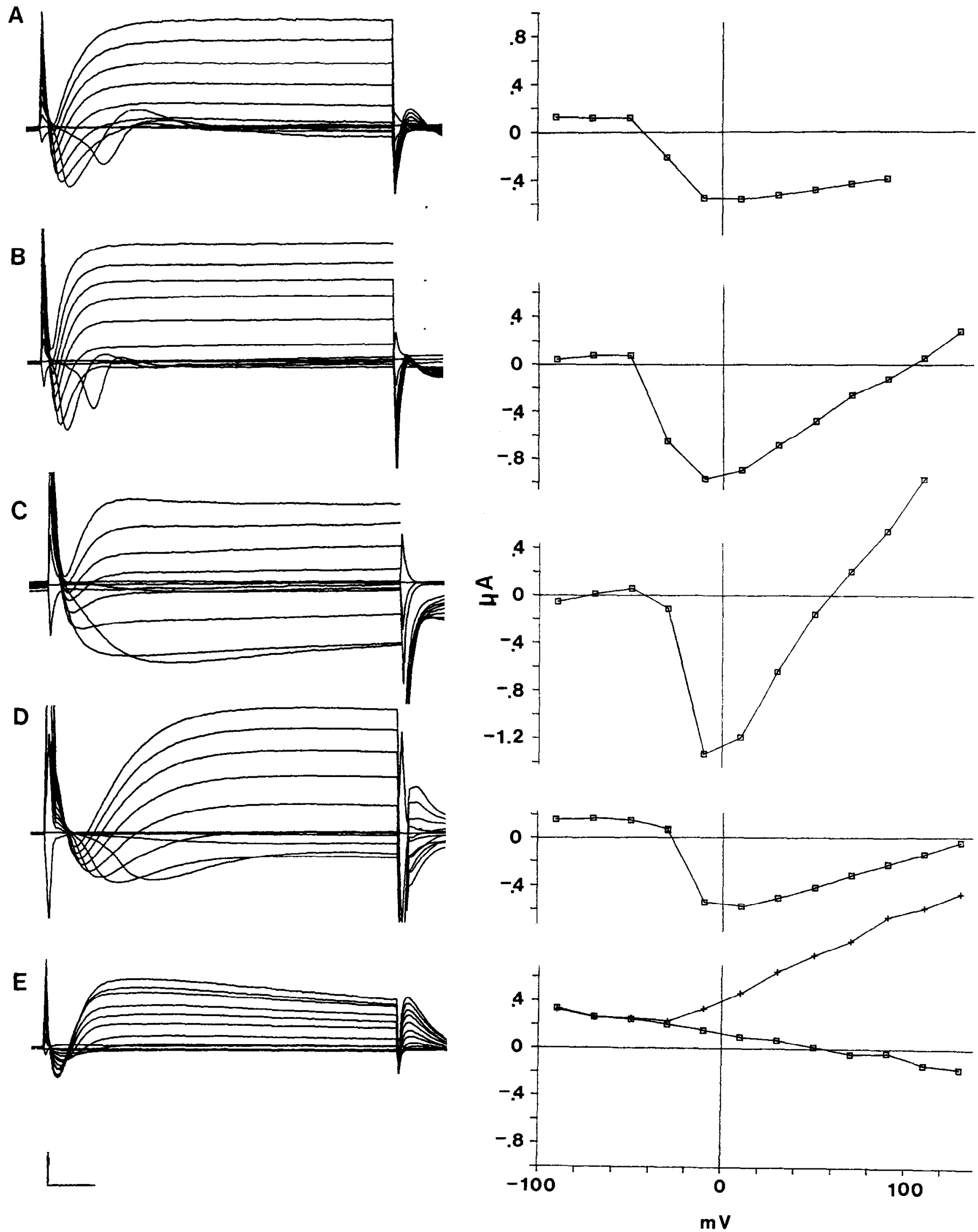

m V

current and crosses give outward current measurements made just before the termination of the voltage step. The holding potential was $-70 \mathrm{mV}$ and $20 \mathrm{mV}$ voltage steps were delivered from -80 to $+140 \mathrm{mV}$. Scale bars in $A-C$ and $E, 500 \mathrm{pA}, 4 \mathrm{msec} ;$ in $D, 500 \mathrm{pA}, 2 \mathrm{msec}$. 

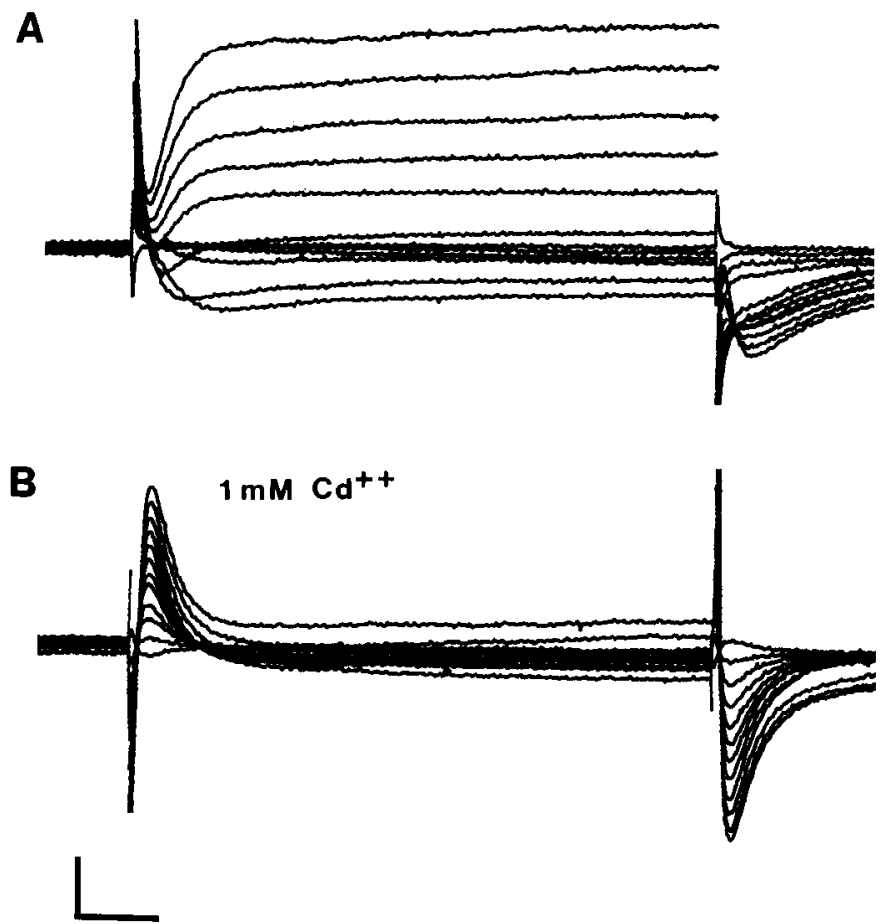

Figure 7. Inward current in a club neuron $(A)$ is blocked by $1 \mathrm{~mm}$ $\mathrm{CdCl}_{2}(B)$, suggesting that this current is carried by $\mathrm{Ca}^{2+}$ ions. Scale bars, $500 \mathrm{pA}, 5$ msec.

made in the current-clamp mode. The cell was quiescent and stable at a resting potential (imposed by the contents of the patch pipette) of $-69 \mathrm{mV}$. A $50 \mathrm{msec}$ depolarizing current pulse passed from the electrode caused the cell to respond with a positive-going response, which outlasted the stimulus by 150 msec. Slightly weaker pulses caused the membrane to return to its resting state with an exponential time course (not shown). Slightly stronger depolarizing pulses evoked a train of action potentials during the positive response period. When the membrane was depolarized with continuous DC current, the cell responded with bursts of action potentials.

Patch-clamp recordings made from freshly dispersed stage- 5 cells in PN-only cultures yield predominantly outward currents (data not shown). When the cultures are allowed to grow for a week or more, large inward currents (including those which might underlie an action potential) are recorded in addition to the outward currents. This work is at an early stage, and efforts to isolate and characterize individual currents are under way. The findings presented here only serve to establish that these currents develop in culture and resemble neuronal currents. Figure 6 shows the whole-cell currents recorded from each of the 5 morphological types of PNs.

Proximally branching and tracery neurons display similar kinds of inward and outward currents in normal saline. The time course and kinetics of these currents suggest that these cells are developing neuronlike voltage-activated channels. The early inward currents of tracery neurons (Fig. $6 B$ ) have faster rise times than those of proximally branching neurons (Fig. 6A). Moreover, the late outward currents observed in tracery neurons are typically larger than those of proximally branching neurons. The activation point for the early inward current in both of these types of cells is roughly $-50 \mathrm{mV}$.
$C l u b$ (Fig. 6C) and radial (Fig. 6D) neurons exhibit slow inward currents. The currents in $c l u b$ neurons activate at $-30 \mathrm{mV}$ and inactivate little over the course of the $30-\mathrm{msec}$ voltage step. Both inward and outward currents are blocked in $c l u b$ ncurons by $1 \mathrm{~mm} \mathrm{CdCl}_{2}$ (Fig. 7), a result suggesting that the inward component is a $\mathrm{Ca}^{2+}$ current and the outward component, a $\mathrm{Ca}^{2+}$-activated $\mathrm{K}^{+}$current. In radial neurons, the inward current is slow and is first inward and then outward. The inward current activates at about $-50 \mathrm{mV}$.

The whole-cell currents in bifurcating neurons (Fig. 6E) show an early inward component and a late outward component. Work is under way to characterize the currents in this infrequently observed cell type.

Voltage control is often poor, as is evident from the erratic tail currents in many of our records. Nevertheless, these records allow us to conclude that voltage-gated currents are expressed in our cultures and help to make the classification of neurons more certain.

\section{Cultures enriched in $L N S$}

When the cells from the lateral cell group of the AL are cultured alone, we observe 3 types of neurons that are not found in the PN-only cultures (Fig. 8). The morphology of 2 of these types of cells suggests that they are LNs: (1) symmetrical cells, which have multiple finely branched neurites radiating from a single point close to a large soma (Fig. $8 A$ ); and (2) splayed cells, which have a phase-dark, irregularly shaped soma and multiple finely branched neurites that all tend to grow in a particular direction and often include flattened regions (Fig. 8R). The third cell type found only in cultures of the lateral cell group, halo cells, have branched neurites radiating from an ovoid soma and a very long, rapidly growing process that extends in a tortuous fashion across the substrate (Fig. 8C). Despite the vigorous outgrowth of neurites and robust morphological development of these 3 types of cells in vitro, whole-cell patch-clamp recordings reveal only outward currents. One possible explanation is that these cells require additional factors to mature. While their morphological characteristics suggest that these cells are LNs, we cannot rule out the possibility that they are classes of PNs unique to the lateral cluster.

Of the 5 cell types that appear in the PN-only cultures as described above, one-the proximally branching neuron-has been recognized often in cultures prepared from the lateral cell group of the AL. Cells resembling club, radial, and tracery neurons also appear in these $\mathrm{LN}$-enriched cultures, but we have not yet followed the morphological and physiological development of such cells in enough detail to be certain of their classification. We have not yet observed cells in these cultures with the morphology characteristic of the bifurcating neuron.

\section{Cells cultured in embo-CM conditioned medium}

We discovered that embo-C.M, I-L15 medium supplemented with TNM-FH medium conditioned by the $M$. sexta embryonic cell line MRRL-CH1 (Eide et al., 1975; see Materials and Methods), gave rise to PN-only cultures that were more robust than those grown in unsupplemented medium. More neurons survive in embo-CM, and we observe qualitatively an increased frequency of branching and faster growth of processes. Furthermore, glial cells, nearly all of which die in I-L15, survive and by 3-4 $\mathrm{d}$ after plating, transform from small phase-dark, solitary cells into cells that are fusiform. Neurons and transformed glial cells that have been grown in embo-CM for $5 \mathrm{~d}$ are shown in 

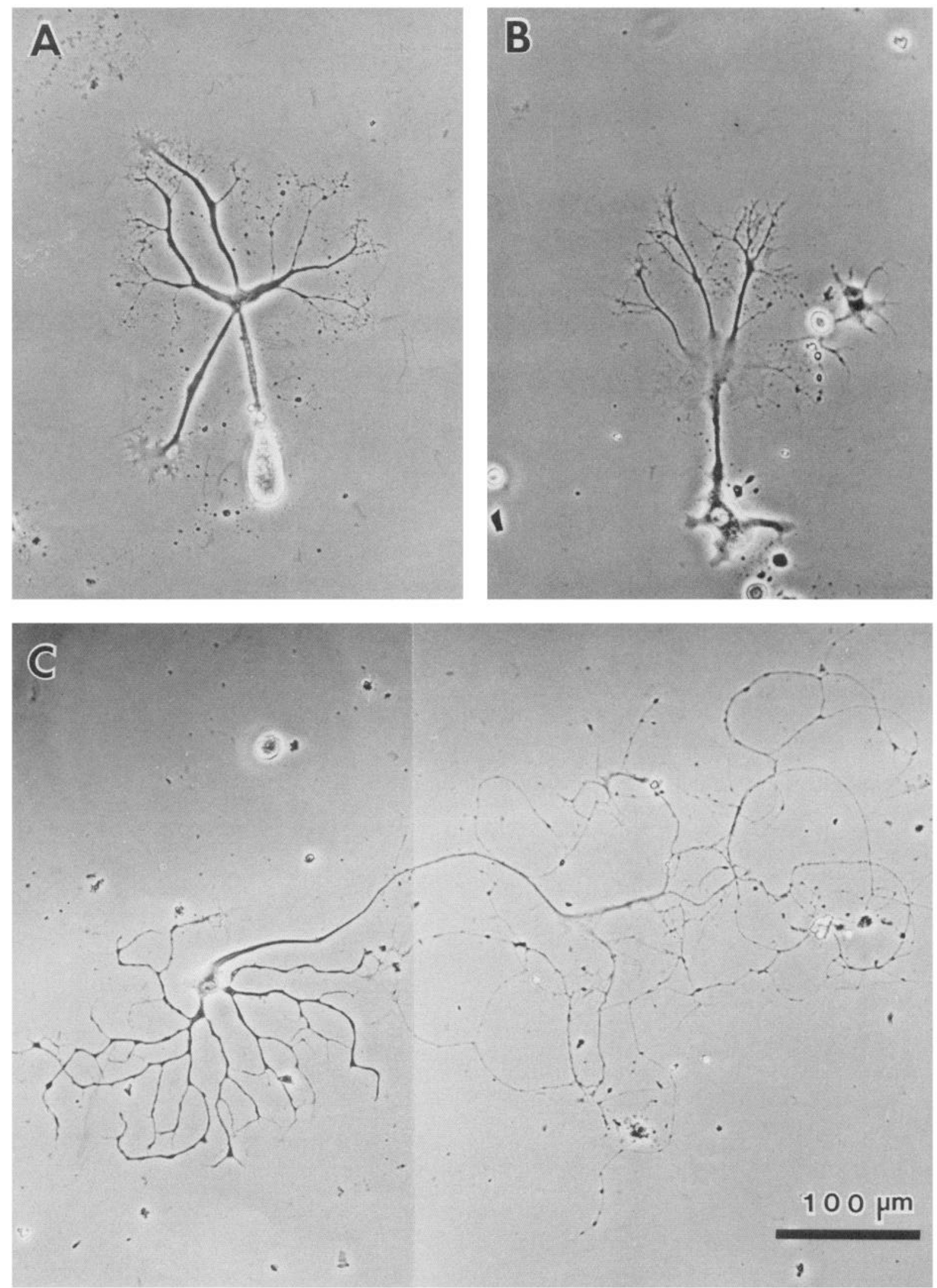

Figure 8. Morphology of cells unique to the lateral group of AL neurons in vitro. All cells exhibit a spray of projections that emanate from a central process. A, A symmetrical cell has multiple finely branched neurites radiating from a single point close to the large phase-bright soma. The ends of some of its processes are tipped with splayed-out structures, while others are not. B, A splayed cell has a phase-dark, asymmetrical soma and multiple finely branched neurites that all tend to grow in a particular direction and often include flattened regions. $C$, A halo cell grows a symmetrical set of processes from its ovoid soma. One projection has thinner processes than the others and branches more profusely as it grows across the surface of the dish. This classification is based upon observations of cultures derived from 22 different dissociation experiments. 


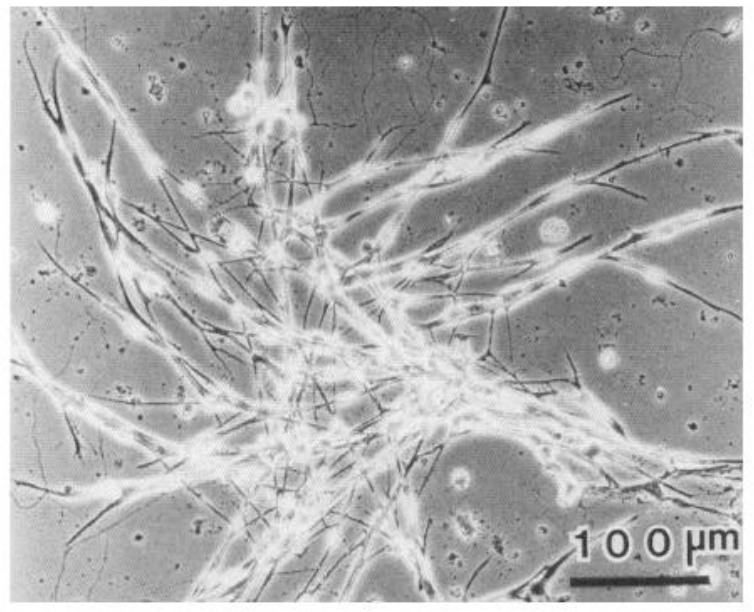

Figure 9. After $9 \mathrm{~d}$ in embo-CM, these cultured cells have become fusiform and apparently adhere to each other.

Figure 9. The glial cells will continue to elongate and fasciculate with one another and with neuronal processes.

These changes occur in embo-CM but not in medium consisting of I-L15 with an equivalent amount of cell-line medium that has not been exposed to MRRL-CH1 cells (unconditioned TNM-FH medium). The TNM-FH medium required by the cell line is based on Grace's insect tissue culture medium (Grace, 1962), which has a $\mathrm{K}^{+}$concentration of $55 \mathrm{mM}$, as compared to the $5.36 \mathrm{~mm}$ present in I-L15. Thus, a medium that consists of $20 \%$ Grace's medium and $80 \%$ I-L15 would have a total $\mathrm{K}^{+}$ concentration 2.85 -fold the normal level, which we estimate would depolarize the cells by roughly $26 \mathrm{mV}$. The effects of embo-CM on neurons and glial cells, however, are not due to an elevated $\mathrm{K}^{+}$concentration; medium made with $20 \%$ TNMFH medium that has not been exposed to the cell-line is ineffectual. Glial cells did not survive, and neuronal survival as well as process outgrowth were reduced. We conclude that the higher $\mathrm{K}^{+}$concentration in embo-CM is not responsible for its beneficial effects and that a substance released by the cell line is responsible. The continuous presence of embo-CM is required for its effect; withdrawal at any time results in death of glial cells and regression of many neuronal processes.

We found that in the absence of embo-CM (i.e., using $80 \%$ I-L15: 20\% unconditioned TNM-FH medium), the PN-only cultures are littered with degenerating and dying cells, and the majority of the remaining neurons have smaller and thinner processes. For example, proximally branching neurons of identical age shown in Figure 10 were grown in the presence (Fig. $10 A$ ) and absence (Fig. $10 B$ ) of embo-CM. Paired cultures grown in embo-CM have thriving neurons and glia. While most cells are sensitive to embo-CM, Figures $10 C$ and $10 D$ illustrate a contrary example. The morphology of this type of cell is similar in embo-CM and in unconditioned medium. In contrast to PNonly cultures, cultures that contain both PNs and LNs, derived either from the whole $\mathrm{AL}$ or from the lateral cell group alone, do not require embo-CM for morphological types of PNs and putative LNs to grow. Because the most heavily dissected preparation, the lateral cell group, can thrive without embo-CM, the requirement for embo-CM apparently does not indicate cell damage.

\section{Glial cell currents}

In embo-CM, glial cells survive and develop a characteristic morphology distinct from that of neurons. These cells display an outward current that activates at roughly $-40 \mathrm{mV}$, turns on slowly, and develops linearly (Fig. 11). None of the inward currents typical of neurons are observed in these cells.

\section{Discussion}

To facilitate developmental and biophysical studies of central olfactory neurons from $M$. sexta brain, we have developed a primary cell culture system in which neurons and glial cells dissociated from M. sexta ALs can thrive. Neurons develop the ability to sustain action potentials in culture and can exhibit patterned activity reminiscent of recordings made in situ. The nonovershooting action potentials recorded from neurons in culture suggest that they have electrically inexcitable somata, as has been shown for insect central neurons in general (Gwilliam and Burrows, 1980; Thomas, 1984). We have monitored the morphological development of these dispersed cells in vitro and have found 8 distinct cell types.

Because the growth substrate and medium are uniform for all cells, the 8 morphological cell types must represent developmental programs that are intrinsic to these neurons. We are now in a position to examine the effects of changes in the environment on the morphological and biophysical properties of these cells. For example, because the PNs develop voltage-gated channels while the LNs do not under our culture conditions, we can now ask whether extrinsic cues such as the steroid hormone 20HE might affect LN differentiation. The neurons in this study were taken from animals at a time when the 20-HE titer is beginning its normal ascent (Warren and Gilbert, 1986), and one might expect, for example, that changes in hormone titer in vitro might induce or permit the expression of further development. We can now systematically test this hypothesis by controlling exposure to 20 -HE in culture.

In this study we have established that voltage-gated membrane currents develop in cultured PNs and that each morphological type of PN exhibits a different and characteristic set of currents. We are now beginning to isolate and study the individual currents. Furthermore, we will use the present culture conditions to provide a control for experiments intended to test the morphological and biophysical effects of other factors that have been implicated by in vivo studies as relevant developmental cues.

We conclude that the fusiform cells without arborizations are glial cells. In patch-clamp, these cells lack the strong inward currents that are normally associated with neurons. Instead, they exhibit outward currents that activate at about $-40 \mathrm{mV}$, have a slow onset, and do not inactivate within $30 \mathrm{msec}$. These cells require the continuous presence of embo-CM to survive. Hence, cultures lacking glial cells can be produced by withholding this conditioning factor for a few days. It is interesting to note that glial cells have not been prominent in other insect tissue culture systems. This experience contrasts with the situation in vertebrate cultures, in which proliferating glial cells must be destroyed with antimitotic agents or by irradiation to prevent them from overgrowing the culture dish. We now have the opportunity to explore the morphological and biophysical properties of insect glial cells in culture.

We are interested in the structural and functional development of the olfactory system at the molecular, cellular, and 

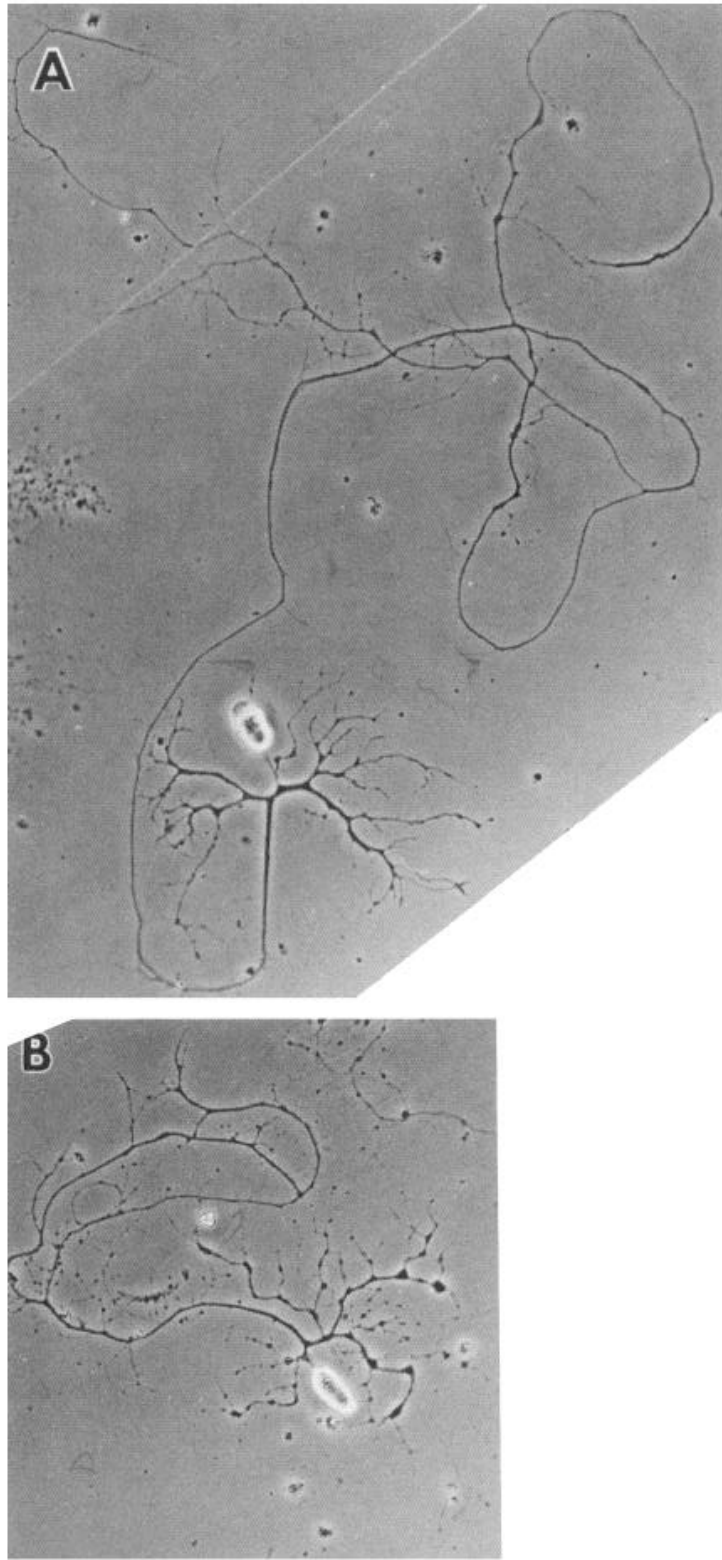
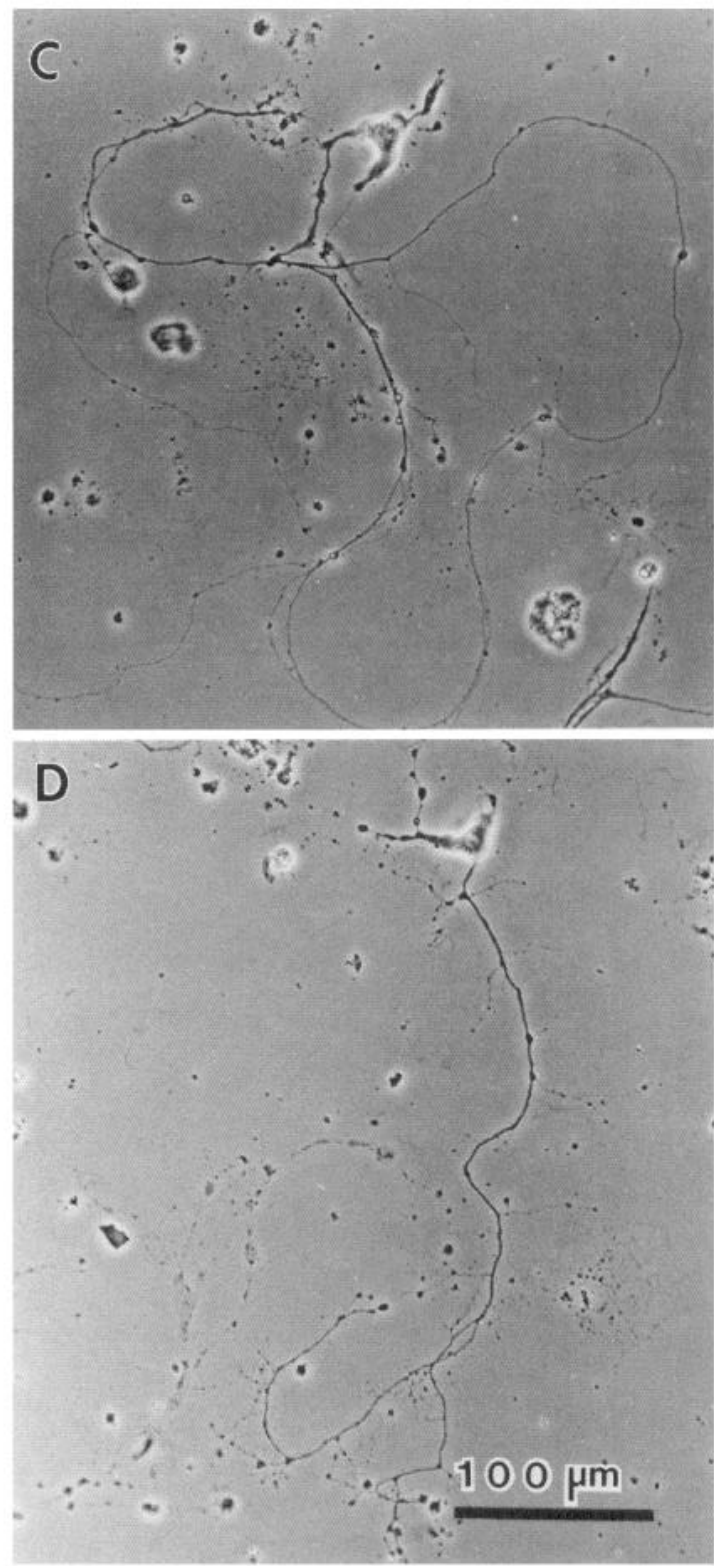

Figure 10. AL cells dispersed from stage-5 pupae and maintained in culture for $20 \mathrm{~d}$. A proximally branching neuron exhibits more extensive process outgrowth in embo-CM medium $(A)$ than in unconditioned medium $(B)$. In contrast, a radial neuron exhibits similar morphology in either embo-CM $(C)$ or unconditioned medium $(D)$.

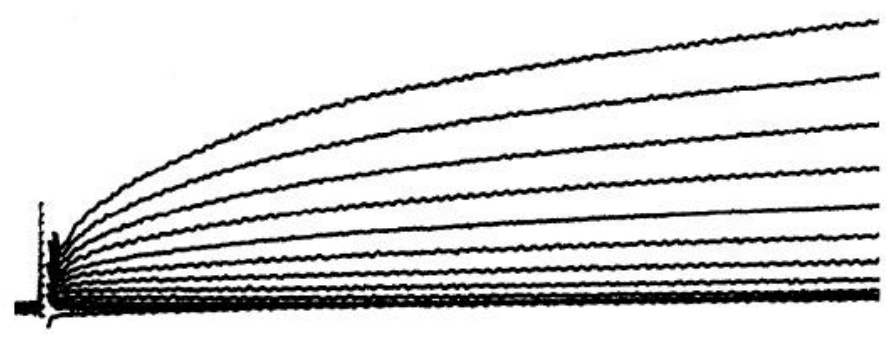

Figure 11. Whole-cell current of a fusiform glial cell. An outward current that activates at roughly $-40 \mathrm{mV}$, turns on slowly, and develops linearly is observed. The holding potential was $-70 \mathrm{mV} ; 20 \mathrm{mV}$ voltage steps were delivered from -80 to $+140 \mathrm{mV}$. Scale bars, $500 \mathrm{pA}, 4$ msec. systems levels. The $M$. sexta central olfactory pathway is a useful model system that has yielded a wealth of information about ALs of animals undergoing metamorphic adult development as well as ALs of intact adults. We have extended the utility of this system by establishing methods for long-term studies of AL cells in primary cell-culture. Only in vitro can one control precisely the environment of individual neurons and make accurate measurements to quantify morphological and physiological properties of single neurons.

\section{References}

Bell, R. A., and F. A. Joachim (1976) Techniques for rearing laboratory colonies of tobacco hornworms and pink bollworms. Ann. Ent. Soc. Am. 69: 365-373.

Bornstein, M. B. (1958) Reconstituted rat-tail collagen used as a substrate for tissue cultures on coverslips in Maximow slides and roller tubes. Lab. Invest. 7: 134-137. 
Bray, D. (1970) Surface movements during the growth of single explanted neurons. Proc. Natl. Acad. Sci. USA 65:-905-910.

Chen, J. S., and R. Levi-Montalcini (1969) Axonal outgrowth and cell migration in vitro from nervous system of cockroach embryos. Science 166: 631-632.

Chiquet, M., and S. E. Acklin (1986) Attachment to Con A or extracellular matrix initiates rapid sprouting by cultured leech neurons. Proc. Natl. Acad. Sci. USA 83: 6188-6192.

Christensen, T. A., and J. G. Hildebrand (1987) Functions, organization, and physiology of the olfactory pathways in the lepidopteran brain. In Arthropod Brain: Its Evolution, Development, Structure and Functions, A. P. Gupta, ed., pp. 457-484, Wiley, New York.

Christensen, T. A., and J. G. Hildebrand (1988) Frequency coding by central olfactory neurons in the sphinx moth Manduca sexta. Chem. Senses 13: 123-130.

DeGeorge, J. J., N. Slepecky, and S. Carbonetto (1985) Concanavalin A stimulates neuron-substratum adhesion and nerve fiber outgrowth in culture. Dev. Biol 111: 335-351.

Dewhurst, S., and D. Beadle (1985) Culturing nerve cells and tissues from insects in vitro. In Neurochemical Techniques in Insect Research, H. Breer and T. A. Miller, eds., pp. 201-222, Springer-Verlag, New York.

Eide, P. E., J. M. Caldwell, and E. P. Marks (1975) Establishment of two cell lines from embryonic tissue of the tobacco hornworm, Manduca sexta (L.). In Vitro 11: 395-399.

Fenwick, E. M., A. Marty, and E. Neher (1982) A patch-clamp study of bovine chromaffin cells and of their sensitivity to acetylcholine. J. Physiol. (Lond.) 331: 577-597.

Furshpan, E. J., S. C. Landis, S. G. Matsumoto, and D. D. Potter (1986) Synaptic functions in rat sympathetic neurons in microcultures. I. Secretion of norepinephrine and acetylcholine. J. Neurosci. 6: 10611079.

Giles, D. P., and P. N. R. Usherwood (1985) Locust nymphal neurones in culture: A new technique for studying the physiology and pharmacology of insect central neurones. Comp. Biochem. Physiol. 80C: 53-59.

Grace, T. C. C. (1962) Establishment of four strains of cells from insect tissues grown in vitro. Nature 195: 788-789.

Gwilliam, G. F., and M. Burrows (1980) Electrical characteristics of the membrane of an identified insect motor neurone. J. Exp. Biol. 86: $49-61$

Hamill, O. P., A. Marty, E. Neher, B. Sakmann, and F. J. Sigworth (1981) Improved patch-clamp techniques for high resolution current recording from cells and cell-free membrane patches. Pfluegers Arch. 391: $85-100$.

Hawrot, E., and P. H. Patterson (1979) Long-term culture of dissociated sympathetic neurons. Methods Enzymol. 58: 574-583.

Hayashi, J. H., and J. G. Hildebrand (1988) Voltage-gated currents in insect central olfactory neurons in primary culture. Soc. Neurosci. Abstr. 14: 380 .

Hayashi, J. H., and J. G. Hildebrand (1989) Voltage- and ligand-gated currents in cultured neurons from an insect antennal lobe. Soc. Neurosci. Abstr. 15: 1145.

Hildebrand, J. G. (1985) Metamorphosis of the insect nervous system: Influences of the periphery on the postembryonic development of the antennal sensory pathway in the brain of Manduca sexta. In Model Neural Networks and Behavior, A. Selverston, ed., pp. 129-148, Plenum, Now York.

Homberg, U., R. A. Montague, and J. G. Hildebrand (1988) Anatomy of antenno-cerebral pathways in the brain of the sphinx moth Manduca sexta. Cell Tissue Res. 254: 255-281.

Homberg, U., T. A. Christensen, and J. G. Hildebrand (1989) Structure and function of the deutocerebrum in insects. Annu. Rev. Entomol. 34: 477-501.

Hoskins, S. G., U. Homberg, T. G. Kingan, T. A. Christensen, and J. G. Hildebrand (1986) Immunocytochemistry of GABA in the antennal lobes of the sphinx moth Manduca sexta. Cell Tissue Res. 244: 243-252.

Kanzaki, R., E. A. Arbas, N. J. Strausfeld, and J. G. Hildebrand (1989) Physiology and morphology of projection neurons in the antennal lobe of the male moth Manduca sexta. J. Comp. Physiol. A 165:427453.

Kent, K. S., S. G. Hoskins, and J. G. Hildebrand (1987) A novel serotonin-immunoreactive neuron in the antennal lobe of the sphinx moth Manduca sexta persists throughout postembryonic life. J. Neurobiol. 18: 451-465.

Kingan, T. G., and J. G. Hildebrand (1985) $\gamma$-Aminobutyric acid in the central nervous system of metamorphosing and mature Manduca sexta. Insect Biochem. 15:667-675.

Mains, R. E., and P. H. Patterson (1973) Primary cultures of dissociated sympathetic neurons. I. Establishment of long-term growth in culture and studies of differentiated properties. J. Cell Biol. 59: 329 345.

Matsumoto, S. G., and J. G. Hildebrand (1981) Olfactory mechanisms in the moth Manduca sexta: Response characteristics and morphology of central neurons in the antennal lobes. Proc. R. Soc. Lond. [Biol.] 213: $249-277$.

Mitsuhashi, J., and K. Maramorosch (1964) Leafhopper tissue culture: Embryonic, nymphal, and imaginal tissues from aseptic insects. Contrib. Boyce Thompson Inst. 22: 435-460.

Narahashi, T. (1963) The properties of insect axons. In Advances in Insect Physiology, Vol. 1, J. W. L. Beament, J. E. Treherne, and V. B. Wigglesworth, eds., pp. 175-256, Academic, New York.

Pichon, Y., D. B. Sattelle, and N. J. Lane (1972) Conduction processes in the nerve cord of the moth Manduca sexta in relation to its ultrastructure and haemolymph ionic composition. J. Exp. Biol. 56: 717734.

Pinnock, R. D., and D. B. Sattelle (1987) Dissociation and maintenance in vitro of neurones from adult cockroach (Periplaneta americana) and housefly (Musca domestica). J. Neurosci. Methods 20 . 195-202.

Prescott, D. J., J. G. Hildebrand, J. R. Sanes, and S. Jewett (1977) Biochemical and developmental studies of acetylcholine metabolism in the central nervous system of the moth, Manduca sexta. Comp. Biochem. Physiol. 56C: 77-84.

Ross, W. N., H. Arechiga, and J. G. Nicholls (1987) Optical recording of calcium and voltage transients following impulses in cell bodies and processes of identified leech neurons in culture. J. Neurosci. 7 . $3877-3887$.

Sanes, J. R., and J. G. Hildebrand (1976) Structure and development of antennae in a moth, Manduca sexta (Lepidoptera: Sphingidae). Dev. Biol. 51: 282-299.

Sanes, J. R., D. J. Prescott, and J. G. Hildebrand (1977) Cholinergic neurochemical development of normal and deafferented antennal lobes in the brain of the moth, Manduca sexta. Brain Res. 119: 389-402.

Schneiderman, A. M., S. G. Matsumoto, and J. G. Hildebrand (1982) Trans-sexually grafted antennae influence development of sexually dimorphic neurones in moth brain. Nature 98: 844-846.

Seecof, R. L., and J. J. Donady (1972) Factors affecting Drosophila neurone and myocyte differentiation in vitro. Mech. Ageing. Dev. 1: 165-174.

Stengl, M., and J. G. Hildebrand (1988) Immunocytochemical identification of olfactory receptor neurons from male Manduca sexta pupae in vitro. Soc. Neurosci. Abstr. 14: 382.

Stengl, M., and J. G. Hildebrand (1990) Insect olfactory neurons in vitro: Morphological and immunocytochemical characterization of male-specific antennal receptor cells from developing antennae of male Manduca sexta. J. Neurosci. 10: 837-847.

Stengl, M., F. Zufall, H. Hatt, J. Dudel, and J. G. Hildebrand (1989) Patch-clamp analysis of male Manduca sexta olfactory receptor neurons in primary cell culture. Soc. Neurosci. Abstr. 15: 751.

Thomas, M. V. (1984) Voltage clamp analysis of a calcium mediated potassium conductance in cockroach (Periplaneta americana) central neurones. J. Physiol. (Lond.) 350: 159-178

Tolbert, L. P., and J. G. Hildebrand (1981) Organization and synaptic ultrastructure of glomeruli in the antennal lobes of the moth Manduca sexta: A study using thin sections and freeze-fracture. Proc. Roy. Soc. Lond. [Biol.] 213: 279-301.

Tolbert, L. P., S. G. Matsumoto, and J. G. Hildebrand (1983) Development of synapses in the antennal lobes of the moth Manduca sexta during metamorphosis. J. Neurosci. 3: 1158-1175.

Waldrop, B., and J. G. Hildebrand (1989) Physiology and pharmacology of acetylcholinergic responses of interneurons in the antennal lobe of the moth Manduca sexta. J. Comp. Physiol. A 164: 433-441.

Waldrop, B., T. A. Christensen, and J. G. Hildebrand (1987) GABAmediated synaptic inhibition of projection ncurons in the antennal lobes of the sphinx moth Manduca sexta. J. Comp. Physiol. A 161: 23-32. 
Warren, J. T., and L. I. Gilbert (1986) Ecdysone metabolism and distribution during the pupal-adult development of Manduca sexta. Insect Biochem. 16: 65-82.
Yunker, C. E., F. L. Vaughn, and J. Cory (1967) Adaptation of an insect cell line (Grace's Antheraea cells) to medium free of insect hemolymph. Science 155: 1565-1566. 